\title{
Effects of Dairy Cow Genotype with Two Planes of Nutrition on Energy Partitioning Between Milk and Body Tissue
}

\author{
T. Yan, ${ }^{1}$ C. S. Mayne, T. W. J. Keady, and R. E. Agnew \\ The Agricultural Research Institute of Northern Ireland, Hillsborough, BT26 6DR, UK
}

\begin{abstract}
The data used in the present study were derived from a 2 (genotype) $\times 2$ (plane of nutrition) factorial design production study using Holstein-Friesian $(\mathrm{n}=32)$ and Norwegian $(\mathrm{n}=32)$ first-lactation dairy cattle offered grass silage-based diets from 1 to 44 wk of lactation. The high nutrition diet had concentrate inclusions (g/ $\mathrm{kg}$ of dry matter) of 600,500 , and 400 for lactation days of $<101,101$ to 200 , and $>200$, respectively, and the low nutrition diet included concentrates at 300,200, and 100 for the same periods. Dietary metabolizable energy (ME) concentrations were measured in calorimetric chambers at lactation d 80,160, and 240 respectively, and then applied to production data to calculate ME intake. From wk 1 to 44 of lactation, Holstein-Friesian cows had a consistently lower accumulated live weight gain and body condition score, and a consistently higher ME intake and milk energy output than Norwegian cows, irrespective of the plane of nutrition. Compared with Norwegian cows using mean data derived from the 2 planes of nutrition, Holstein-Friesian cows produced a significantly higher proportion of milk energy output over ME intake in early and mid lactation, although this increase was not significant in late lactation. In contrast, Holstein-Friesian cows partitioned a significantly lower proportion of ME intake into body tissue than Norwegian cows in early lactation, although the differences were not significant in mid or late lactation. When ME intake and energy used for maintenance, milk, and body tissue were taken into account, the efficiency of ME use for lactation was similar between the 2 genotypes offered the high or low concentrate diet during the whole lactation. It is concluded that Holstein-Friesian cows can produce more milk energy than Norwegian cows, mainly as a result of higher ME intake and because of a greater ability to partition more energy into milk and less into body tissue. The effect on energy partitioning mainly occurs in early and midlactation and is particularly evident with high concentrate diets.
\end{abstract}

Received August 17, 2005.

Accepted October 20, 2005

${ }^{1}$ Corresponding author: tianhai.yan@dardni.gov.uk
Key words: energetic efficiency, energy partitioning, Holstein-Friesian cow, Norwegian cow

\section{INTRODUCTION}

Holstein-Friesian cattle are the predominant breed of dairy cattle in Northern Ireland. Breeding programs for the Holstein-Friesian have historically focused on improved milk production with little emphasis on functional traits such as fertility or disease resistance. In contrast, Norwegian dairy cattle have been bred using a multitrait selection procedure for $25 \mathrm{yr}$ and there is evidence that problems associated with disease and fertility have tended to decrease in recent years (Ødegård et al., 2003; Ranberg et al., 2003). These differences in selection procedures for the 2 breeds may have major effects on overall herd output and profitability with the forage-based systems of milk production used in Northern Ireland. One of the important issues that merits investigation is the possibility of breed effects on efficiency of food use and partitioning of nutrients, which may offset the potential advantages of improvements in secondary characteristics. There is increasing evidence in the literature that within the same breed, high genetic merit dairy cows are capable of partitioning more energy into milk and less energy into body tissue than low genetic merit cows (Agnew and Yan, 2000). However, there is little information on this aspect between Holstein-Friesian and Norwegian cows. The objective of the present study was to examine possible differences in energy partitioning and the efficiency of use of ME for lactation $\left(\mathbf{k}_{\mathbf{1}}\right)$ between Holstein-Friesian and Norwegian dairy cows. The data used in the present study were derived from a production study in which the 2 genotypes were offered diets from wk 1 to 44 of lactation. The ME concentrations in diets were measured in calorimetric chambers using a subgroup of experimental cows.

\section{MATERIALS AND METHODS}

\section{Experimental Design, Animals, and Diets}

Two datasets for lactating dairy cows were used in the present study, a production data set, and an energy 
metabolism data set. The 2 datasets were derived from a single study with the overall objective of evaluating the effects of cow genotype and plane of nutrition on milk production and energy metabolism of lactating dairy cows.

The study was a 2 (cow genotype) $\times 2$ (plane of nutrition) factorial continuous design experiment with a recording period from calving to $44 \mathrm{wk}$ of lactation. The 2 genotypes of animals were first-lactation HolsteinFriesian (Hol; n = 32, PIN $(2000)$ £44) and Norwegian [Nor; $n=32$, Total Merit Index (2000) of 10.1] dairy

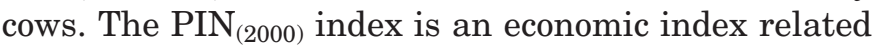
to genetic merit of the dairy cow (Holstein Journal, 2000). They were selected as in-calf heifers in the Netherlands and Norway, respectively, and arrived at the Agricultural Research Institute of Northern Ireland approximately 1 mo before calving. These animals were representative of the top $0.5 \%$ and $10 \%$ of the HolsteinFriesian cows in the United Kingdom and Norwegian cows in Norway, respectively. Immediately after calving, the cows were blocked into pairs within each genotype and allocated at random to total mixed diets containing either a high (HC) or low ( $\mathbf{L C})$ proportion of concentrates. The 4 treatments were thus designated Hol-HC, Hol-LC, Nor-HC, and Nor-LC for HolsteinFriesian and Norwegian cows offered diets containing high and low levels of concentrates, respectively. The remainder of the diet was grass silage made from primary regrowth perennial ryegrass herbage. The silage had $\mathrm{pH} 3.87$, ammonia N/total $\mathrm{N}$ of $99 \mathrm{~g} / \mathrm{kg}$ and concentrations of DM, gross energy (GE), CP, ADF, NDF, and ash of $296 \mathrm{~g} / \mathrm{kg}, 18.6 \mathrm{MJ} / \mathrm{kg}$ of DM, 134, 308, 523, and $72 \mathrm{~g} / \mathrm{kg}$ of DM, respectively. The concentrate proportions $(\mathrm{g} / \mathrm{kg}$ of $\mathrm{DM})$ in the high concentrate diet were 600,500 , and 400 and in the low concentrate diet were 300,200 , and 100, for lactation days of $<101,101$ to 200 , and $>200$, respectively. The concentrates consisted of ( $\mathrm{g} / \mathrm{kg}$ of DM) 221 barley, 221 wheat, 305 sugar beet pulp, and 253 soybean meal, and contained DM, GE, $\mathrm{CP}, \mathrm{ADF}, \mathrm{NDF}$, and ash of $867 \mathrm{~g} / \mathrm{kg}, 18.2 \mathrm{MJ} / \mathrm{kg}$ of $\mathrm{DM}, 213,88,205$, and $59 \mathrm{~g} / \mathrm{kg}$ of DM, respectively. The concentrates and silage were completely mixed before feeding and offered ad libitum once daily in the morning in food troughs fitted with continuous automatic weighing equipment and an entry door activated by a radio transponder around each animal's neck. In addition each cow received $160 \mathrm{~g} / \mathrm{d}$ of a mineral-vitamin premix that was completely mixed with concentrates and silage. All cows were loose-housed in cubicle accommodation with free access to water, and milked twice daily starting at 0500 and $1630 \mathrm{~h}$.

Energy metabolism data were measured in digestibility trials and indirect respiration calorimetric chambers using 4 cattle from each treatment at 80,160 , and 240 $\mathrm{d}$ of lactation. The animals were selected from the production study and housed in individual stalls in the metabolism unit for $8 \mathrm{~d}$ with total collection of feces and urine during the final $6 \mathrm{~d}$. They were then transferred to indirect respiration calorimetric chambers and remained there for $3 \mathrm{~d}$ with measurement of gaseous exchange over the final 48 -h period. The obtained methane energy output as a proportion of GE intake was then applied to the data obtained in the digestibility study to determine dietary ME concentration. All cows were fed and managed as described for the production study. The calorimetric chambers used to measure methane production in this study were as described by Gordon et al. (1995) and Yan et al. (2000).

\section{Measurements}

Throughout the study from calving to $44 \mathrm{wk}$ of lactation, total food intake was recorded daily. The silage was sampled daily for oven DM determination and the dried sample bulked over the week for determination of ADF, NDF, and ash concentrations. Fresh silage samples were also taken twice weekly during the production study and daily during the digestibility measurement for determination of toluene $\mathrm{DM}, \mathrm{pH}, \mathrm{CP}$, ammonia-N, GE, lactic acid, VFA, ethanol, and propanol concentrations. Samples of concentrates were taken on $3 \mathrm{~d}$ each week during the production study and daily during the digestibility measurement; the weekly bulked sample was analyzed for oven DM, GE, CP, $\mathrm{ADF}, \mathrm{NDF}$, and ash concentrations. Feces and urine outputs of cows in the digestibility measurements were recorded and sampled daily as a proportion (5\%) of total excretion of feces (by weight) and urine (by volume). The 6-d samples of feces and urine were separately mixed and a representative sample taken for analysis as follows: feces samples were analyzed for oven DM, $\mathrm{N}, \mathrm{GE}, \mathrm{ADF}, \mathrm{NDF}$, and ash concentrations and urine samples were analyzed for GE and $\mathrm{N}$ concentrations. The methods adopted for analysis of silage, concentrate, feces, and urine samples were as described by Mayne and Gordon (1984). Crude protein concentration was determined as Kjeldahl $\mathrm{N} \times 6.25$. Silage $\mathrm{pH}$ was determined using a Corning $113 \mathrm{pH}$-meter (Nova Analytics Corp., Woburn, MA), and ammonia was assayed by bringing the alkalinity of the aqueous extract to $\mathrm{pH}$ 10 and using an Orion 95-12-00 ammonia-sensing gas electrode (Thermo Electron Corp., Waltham, MA). Volatile fatty acids, lactic acid, ethanol, and propanol concentrations in silage samples were analyzed by GLC using a Perkin-Elmer gas chromatograph having a column packed with 80/120 Carbopack B-DA/4\% Carbowax 20m (Sigma-Aldrich Co. Ltd., Poole, UK). 
Milk yields were recorded daily and milk samples were taken during the morning and afternoon milking on 3 consecutive days every second week during the production study and daily during the digestibility measurement. The weekly milk samples were combined to produce one composite sample. The composite sample for each cow was analyzed by the methods of Ling (1963) for fat and lactose concentrations using a Milkoscan model 605 (Foss Electric, Hillerød, Denmark), and protein concentration as Kjeldahl $\mathrm{N} \times 6.38$.

Live weight and BCS of the cattle were determined weekly. Body condition of each cow was determined using the method described by Mulvanny (1977a), with 5 categories from 1 (very thin) to 5 (very fat).

\section{Data Analyses}

The weekly mean animal production data (from lactation wk 1 to 44) were used in the present study to examine effects of animal genotype and plane of nutrition on energy partitioning between milk and body tissue and consisted of live weight (kg), ME intake (MJ/ d), ME/GE (MJ/MJ), milk energy output (MJ/d), and energy balance $(\mathrm{MJ} / \mathrm{d})$. Live weight and GE intake were directly measured. The ME intake was calculated from DM intake (production trial) and dietary ME concentration (energy metabolism study). Dietary ME concentration was estimated as the difference between GE intake (digestibility trials), energy outputs from feces and urine (digestibility trials), and methane energy output. Methane energy output was calculated as GE intake (digestibility trial) multiplied by methane energy output as a proportion of total GE intake as determined in calorimetric chambers. Milk energy output was calculated from actual milk yield and composition using the equation of Tyrrell and Reid (1965; Eq. [1]):

$$
\begin{gathered}
E_{1}=(0.0384 \text { fat }+0.0223 \text { protein } \\
+0.0199 \text { lactose }-0.108) \times \text { milk yield }
\end{gathered}
$$

where $\mathrm{E}_{1}$ is milk energy output (MJ/d) and units for fat, protein, and lactose in milk are $\mathrm{g} / \mathrm{kg}$ and milk yield is in $\mathrm{kg} / \mathrm{d}$.

Energy balance was calculated as the difference between ME intake and ME requirements for maintenance $\left(\mathbf{M E}_{\mathbf{m}}\right)$ and lactation multiplied by the efficiency of ME use for live weight gain using models of the Agricultural and Food Research Council (AFRC, 1990; Eq. [2] to [7]).

$$
\mathrm{EB}=\left(\mathrm{ME} \text { intake }-\mathrm{ME}_{\mathrm{m}}-\mathrm{ME}_{\mathrm{l}}\right) \times \mathrm{k}_{\mathrm{g}}
$$

where

$$
\begin{gathered}
\mathrm{ME}_{\mathrm{m}}=\left(0.53 \times(\mathrm{LW} / 1.08)^{0.67}+0.0091 \mathrm{LW}\right) / \mathrm{k}_{\mathrm{m}} \\
\mathrm{ME}_{1}=\mathrm{E}_{1} / \mathrm{k}_{\mathrm{l}} \\
\mathrm{k}_{\mathrm{m}}=0.35 \times \mathrm{ME} / \mathrm{GE}+0.503 \\
\mathrm{k}_{\mathrm{l}}=0.35 \times \mathrm{ME} / \mathrm{GE}+0.42 \\
\mathrm{k}_{\mathrm{g}}=0.95 \mathrm{k}_{1}
\end{gathered}
$$

where EB is energy balance $(\mathrm{MJ} / \mathrm{d}) ; \mathrm{E}_{1}$ is milk energy output (MJ/d); $\mathrm{k}_{\mathrm{g}}$ and $\mathrm{k}_{\mathrm{m}}$ are the efficiencies of ME use for live weight gain and maintenance respectively; LW is live weight (kg); $\mathrm{ME}_{1}$ and $\mathrm{ME}_{\mathrm{m}}$ are $\mathrm{ME}$ requirements for lactation and maintenance $(\mathrm{MJ} / \mathrm{d})$, respectively.

The $\mathrm{ME}_{\mathrm{m}}$ calculated from AFRC (1990; Eq. [3]) was multiplied by 1.25 , and this adjusted $\mathrm{ME}_{\mathrm{m}}$ was then used in Eq. [2]. The adjustment was based on the finding of Agnew and Yan (2000) that $\mathrm{ME}_{\mathrm{m}}$ for lactating dairy cows was $0.62 \mathrm{MJ} / \mathrm{kg}^{0.75}$ when using regression techniques on calorimetric data published worldwide between 1973 and 1999. This value $\left(0.62 \mathrm{MJ} / \mathrm{kg}^{0.75}\right)$ was approximately $25 \%$ higher than that calculated from AFRC (1990) using the current data set.

The ME intake, milk energy output and estimated energy balance were then used to examine the partitioning of consumed ME between milk and body tissue and $\mathrm{k}_{1}$ (Eq. [8] to [10]; AFRC, 1990):

$$
\mathrm{k}_{\mathrm{l}}=\mathrm{E}_{1(0)} /\left(\mathrm{ME} \text { intake }-\mathrm{ME}_{\mathrm{m}}\right)
$$

where:

$$
\begin{aligned}
& \mathrm{E}_{1(0)}=\mathrm{E}_{1}+0.95 \mathrm{~EB} \text { if } \mathrm{EB}>0 \\
& \mathrm{E}_{1(0)}=\mathrm{E}_{1}+0.84 \mathrm{~EB} \text { if } \mathrm{EB}<0
\end{aligned}
$$

where EB is energy balance $(\mathrm{MJ} / \mathrm{d}) ; \mathrm{E}_{1}$ is milk energy output $(\mathrm{MJ} / \mathrm{d}) ; \mathrm{E}_{1(0)}$ is milk energy output adjusted for zero energy balance $(\mathrm{MJ} / \mathrm{d})$.

\section{Statistical Analyses}

The effects of cow genotype and plane of nutrition on live weight gain, BCS, ME intake, milk energy output, energy balance, and energetic efficiencies were analyzed using 2-way (cow genotype vs. plane of nutrition) ANOVA with no blocking. The data used were averaged for individual cows either from the whole lactation (wk 2 to 44 ), early (wk 2 to 15 ), mid (wk 16 to 30 ), or late (wk 31 to 44) lactation, when the levels of concentrates included in the diets were changed. The statistical program used in the present study was Genstat 6.1 (6th edition; Lawes Agricultural Trust, Rothamsted, UK). 
Table 1. The mean, standard deviation (SD), and range data on live weight, BCS, ME intake and output, and efficiencies of ME use over a 44 -wk period

\begin{tabular}{|c|c|c|c|c|}
\hline & Mean & SD & Minimum & Maximum \\
\hline \multicolumn{5}{|l|}{ Holstein-Friesian cows } \\
\hline Live weight $(\mathrm{kg})$ & 508 & 48.2 & 416 & 606 \\
\hline Live weight gain $^{1}(\mathrm{~kg} / \mathrm{d})$ & 0.13 & 0.215 & -0.34 & 0.49 \\
\hline BCS & 2.4 & 0.25 & 2.0 & 3.0 \\
\hline ME intake (MJ/d) & 169.4 & 27.90 & 117.7 & 211.3 \\
\hline Milk energy output (MJ/d) & 64.9 & 12.54 & 47.2 & 86.4 \\
\hline Energy balance $^{2}(\mathrm{MJ} / \mathrm{d})$ & 3.6 & 7.95 & -9.7 & 24.5 \\
\hline \multicolumn{5}{|l|}{ Norwegian cows } \\
\hline Live weight $(\mathrm{kg})$ & 498 & 45.6 & 412 & 607 \\
\hline Live weight gain ${ }^{1}(\mathrm{~kg} / \mathrm{d})$ & 0.23 & 0.219 & -0.24 & 0.67 \\
\hline BCS & 2.9 & 0.24 & 2.5 & 3.5 \\
\hline ME intake $(\mathrm{MJ} / \mathrm{d})$ & 156.9 & 24.03 & 110.9 & 201.4 \\
\hline Milk energy output (MJ/d) & 55.6 & 8.60 & 40.8 & 71.8 \\
\hline Energy balance $(\mathrm{MJ} / \mathrm{d})^{2}$ & 5.0 & 7.34 & -6.3 & 21.0 \\
\hline
\end{tabular}

${ }^{1}$ Live weight gain $(\mathrm{kg} / \mathrm{d})=$ mean difference in live weight between current and previous week and then divided by 7 .

${ }^{2}$ Energy balance was estimated from AFRC (1990).

\section{RESULTS}

The data obtained from the present study over wk 2 to 44 of lactation are presented in Table 1 . HolsteinFriesian cows had higher live weight, ME intake, and milk energy output than Norwegian animals, whereas Holstein-Friesians had a lower live weight gain, BCS, and estimated energy balance. Because the primary objective of the present study was to compare energy use between Holstein-Friesian and Norwegian cows, the results reported will concentrate on effects of cow genotype.

\section{Effects on Live Weight Gain and BCS}

Effects of cow genotype and plane of nutrition on accumulated live weight gain and average BCS are presented in Figure 1. Cows on all 4 treatments lost weight after calving with the highest loss for Hol-LC cows; this loss on the 4 treatments ceased at approximately wk 7 of lactation. Accumulated live weight gain was consistently higher for Norwegian than Holstein-Friesian cows, irrespective of the plane of nutrition. The BCS of cows followed the same trend as accumulated live weight gain; that is, it decreased during the first few weeks of lactation and then increased thereafter. Unlike the effects on live weight gain, the 2 groups of Norwegian cows had consistently higher BCS than the 2 groups of Holstein-Friesian cows. It is worth noting that live weight and BCS for Hol-LC cows did not recover to the values recorded at wk 1 of lactation.

Statistical analyses on effects of cow genotype and plane of nutrition are presented in Tables 2 to 5 for the whole, early, mid, and late lactation, respectively. Cow genotype had no significant effect on live weight for the whole lactation or any stage of lactation, although
Holstein-Friesian cows were 9 to $10 \mathrm{~kg}$ heavier than Norwegian cows for the whole lactation. Daily live weight gain was lower with Holstein-Friesian than Norwegian cows for the whole and midlactation $(P<0.05)$, with this difference being mainly derived from the low concentrate diet, because live weight gain was similar between Hol-HC and Nor-HC treatments. Norwegian cows had higher BCS $(P<0.001)$ than Holstein-Friesian cows for the whole lactation and each stage of lactation, irrespective of the plane of nutrition.

\section{Effects on ME Intake, Milk Energy Output, and Energy Balance}

Effects of cow genotype and plane of nutrition on ME intake, milk energy output, and calculated energy balance are presented in Figure 2. Holstein-Friesian cows had consistently higher ME intake and milk energy output than Norwegian cows when offered both high and low concentrate diets, with the exception that the difference in ME intake between Hol-LC and NorLC cows disappeared after 25 wk of lactation. Energy balance was higher with Norwegian than HolsteinFriesian cows during early lactation, irrespective of the plane of nutrition. The difference became smaller as lactation progressed and after 28 wk of lactation Hol$\mathrm{HC}$ cows even stored more energy than Nor-HC cows.

Statistical analyses on effects of cow genotype and plane of nutrition are presented in Tables 2 to 5 for whole, early, mid, and late lactation, respectively. Compared with Norwegian cows, Holstein-Friesian cows had a higher ME intake for the whole lactation $(P<$ $0.001)$ and early $(P<0.001)$, mid $(P<0.001)$, and late $(P<0.05)$ lactation, and produced more milk energy for the whole lactation and each stage of lactation $(P<$ 0.001). The higher ME intake of Holstein-Friesian cows 

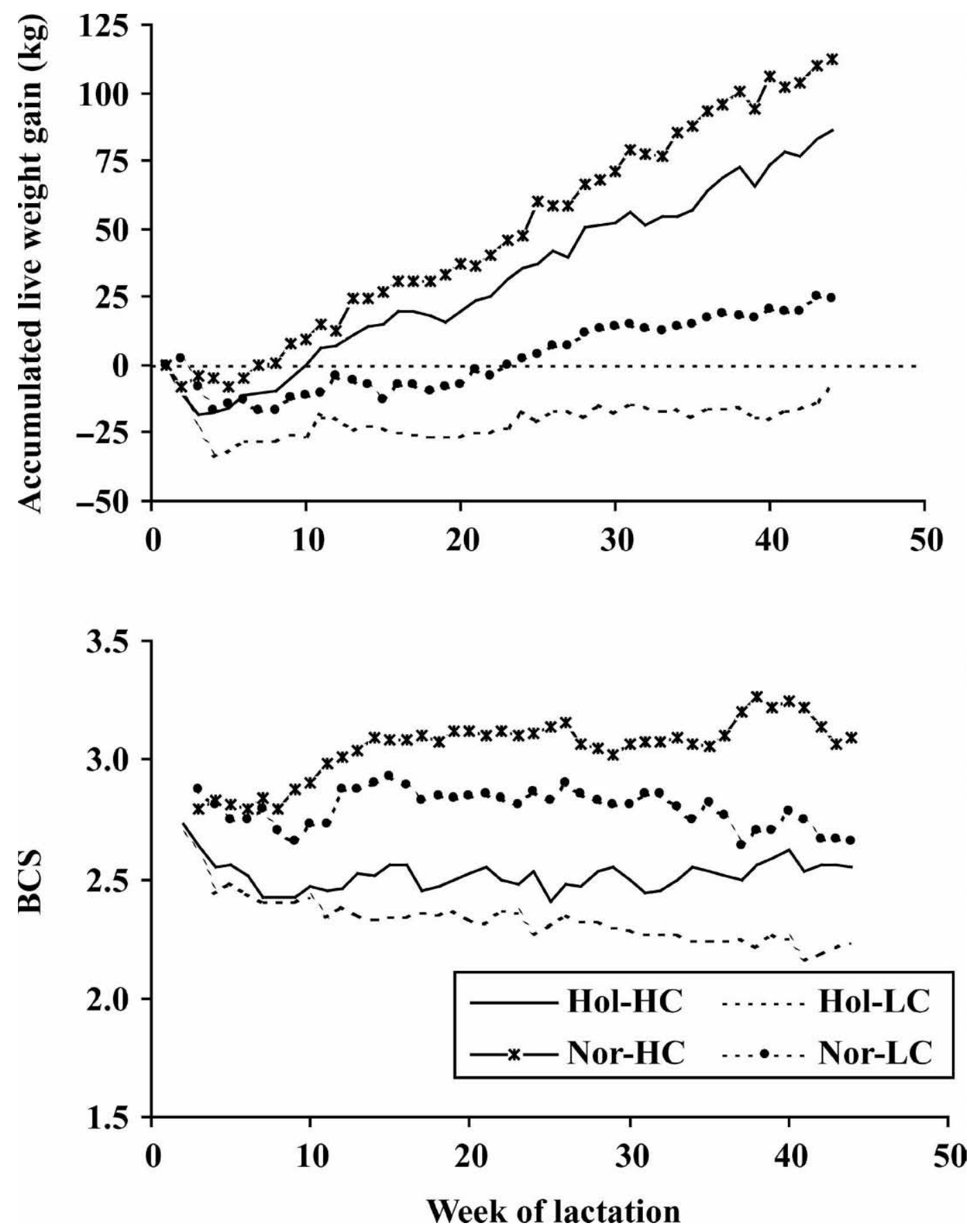

Figure 1. Effects of stage of lactation on accumulated live weight gain (sum of differences between weekly and wk 1 live weight) and BCS in Holstein-Friesian (Hol) and Norwegian (Nor) cows offered high (HC) and low (LC) concentrate diets.

was mainly observed from the high concentrate $\operatorname{diet}(P$ $<0.001)$ because the difference in ME intake between Hol-LC and Nor-LC cows was not significant. The higher milk energy output of Holstein-Friesian cows was obtained with both diets for the whole and each stage of lactation $(P<0.05)$, with the exception that the difference between the 2 genotypes given the low concentrate diet in late lactation was not significant. However, cow genotype had no effect on energy balance for the whole, mid, or late lactation, but in early lactation, Holstein-Friesian cows retained less energy in the body than Norwegian cows $(P<0.01)$ and this effect was mainly derived from the high concentrate $\operatorname{diet}(P$ $<0.001$ ). 
Table 2. Effects of cow genotype and plane of nutrition on live weight, BCS, and energy use during the whole lactation (wk 2 to 44 )

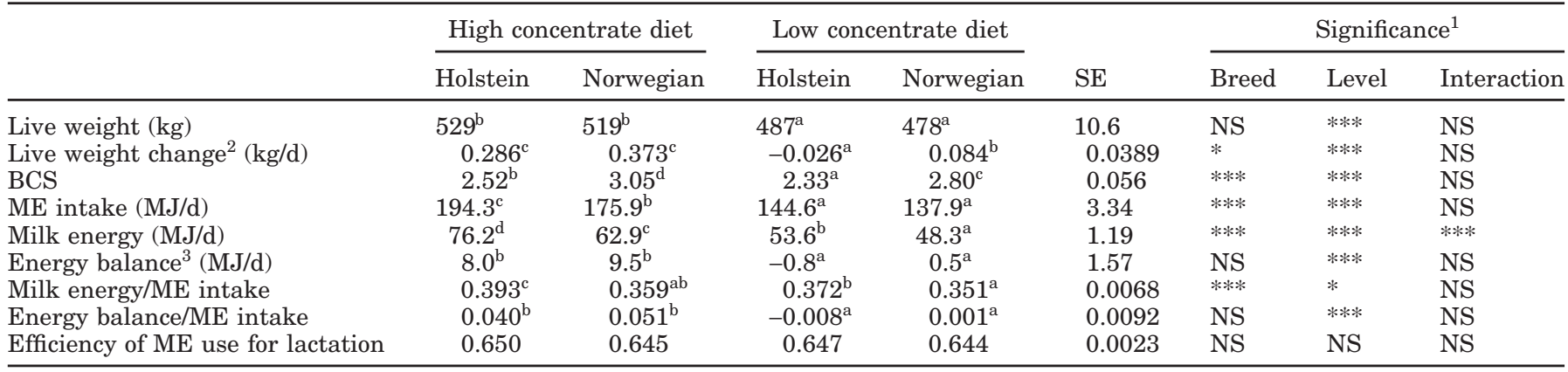

${ }^{\mathrm{a}-\mathrm{d}}$ Superscript means with the same letter in the same row are not significantly different $(P>0.05)$.

${ }^{1} \mathrm{NS}=$ not significant $(P>0.05) ; * P<0.05 ; * * P<0.01$; *** $P<0.001$. Interaction between breed and feeding level for ME intake: $P=0.084$.

${ }^{2}$ Mean difference in live weight between current and previous week and then divided by 7 .

${ }^{3}$ Energy balance was estimated from AFRC (1990).

\section{Effects on Efficiencies of ME Use for Lactation and Live Weight Gain}

Effects of cow genotype and plane of nutrition on energetic efficiencies are presented in Figure 3. Generally, during early lactation, Holstein-Friesian cows partitioned more ME intake into milk and less into body tissue than Norwegian cows, irrespective of the plane of nutrition. This trend gradually disappeared during mid and late lactation. When examining effects on the efficiency for lactation with energy balance adjusted to zero; that is, $\mathrm{k}_{1}$, there were no effects of genotype or plane of nutrition on $k_{1}$ values during the whole lactation.

Statistical analyses on effects of cow genotype and plane of nutrition are presented in Tables 2 to 5 for the whole, early, mid, and late lactation respectively. Holstein-Friesian cows had a higher ratio of milk energy output against ME intake than Norwegian cows for the whole $(P<0.001)$, early $(P<0.001)$, and late $(P$ $<0.01)$ lactation. The difference was mainly derived from the high concentrate diet, because the difference between Hol-LC and Nor-LC cows was not significant for early, mid, or late lactation. Cow genotype had no effect on the ratio of energy balance against ME intake for the whole lactation, although this value was marginally higher in Norwegian cows. In early lactation, Hol$\mathrm{HC}$ cows had lower energy balance as a proportion of ME intake than Nor-HC $(P<0.05)$. Cow genotype had no significant effect on $\mathrm{k}_{1}$ values for the whole lactation, although the $\mathrm{k}_{1}$ value was higher in Holstein-Friesian than in Norwegian cows during early lactation $(P<$ 0.05).

\section{DISCUSSION}

A few long-term studies have reported effects of genetic merit of dairy cows on energy partitioning between milk and body tissue. For example, studies published by Neilson et al. (1983), Veerkamp et al. (1994), and Veerkamp and Emmans (1995) reported differences in energy use of 2 Holstein-Friesian herds that

Table 3. Effects of cow genotype and plane of nutrition on live weight, BCS, and energy use during early lactation (wk 2 to 15)

\begin{tabular}{|c|c|c|c|c|c|c|c|c|}
\hline & \multicolumn{2}{|c|}{ High concentrate diet } & \multicolumn{2}{|c|}{ Low concentrate diet } & $\mathrm{SE}$ & \multicolumn{3}{|c|}{ Significance $^{1}$} \\
\hline Live weight (kg) & 494 & 476 & 483 & 465 & 10.4 & NS & NS & NS \\
\hline BCS & $2.52^{\mathrm{a}}$ & $2.90^{\mathrm{b}}$ & $2.43^{\mathrm{a}}$ & $2.81^{\mathrm{b}}$ & 0.061 & $* * *$ & NS & NS \\
\hline ME intake (MJ/d) & $200.4^{\mathrm{c}}$ & $182.5^{\mathrm{b}}$ & $157.5^{\mathrm{a}}$ & $148.6^{\mathrm{a}}$ & 3.89 & $* * *$ & $* * *$ & NS \\
\hline Milk energy $(\mathrm{MJ} / \mathrm{d})$ & $91.9^{\mathrm{c}}$ & $70.5^{\mathrm{b}}$ & $70.8^{\mathrm{b}}$ & $62.5^{\mathrm{a}}$ & 1.51 & $* * *$ & $* * *$ & $* * *$ \\
\hline Energy balance $^{3}(\mathrm{MJ} / \mathrm{d})$ & $-0.4^{\mathrm{b}}$ & $9.0^{\mathrm{c}}$ & $-8.9^{\mathrm{a}}$ & $-5.6^{\mathrm{ab}}$ & 2.37 & $* *$ & $* * *$ & NS \\
\hline Efficiency of ME use for lactation & $0.663^{b}$ & $0.649^{\mathrm{a}}$ & $0.667^{\mathrm{b}}$ & $0.659^{\mathrm{ab}}$ & 0.0046 & $*$ & NS & NS \\
\hline
\end{tabular}

${ }^{\mathrm{a}-\mathrm{c}}$ Superscript means with the same letter in the same row are not significantly different $(P>0.05)$.

${ }^{1} \mathrm{NS}=$ Not significant $(P>0.05) ; * P<0.05 ; * * P<0.01 ; * * P<0.001$.

${ }^{2}$ Mean difference in live weight between current and previous week and then divided by 7 .

${ }^{3}$ Energy balance was estimated from AFRC (1990). 

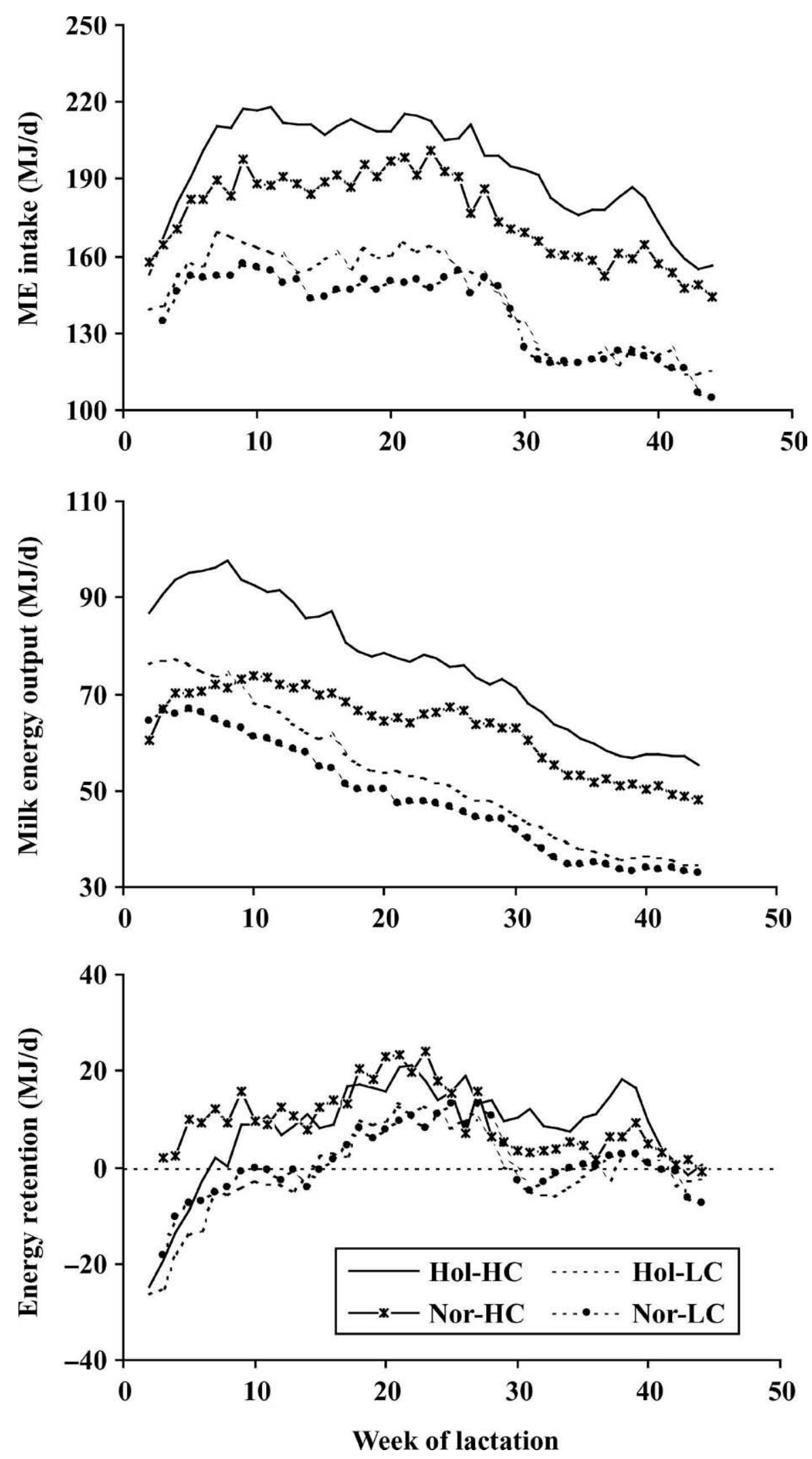

Figure 2. Effects of stage of lactation on ME intake, milk energy output, and estimated energy balance in Holstein-Friesian (Hol) and Norwegian (Nor) cows offered high (HC) and low (LC) concentrate diets. 
Table 4. Effects of cow genotype and plane of nutrition on live weight, BCS, and energy use during midlactation (wk 16 to 30)

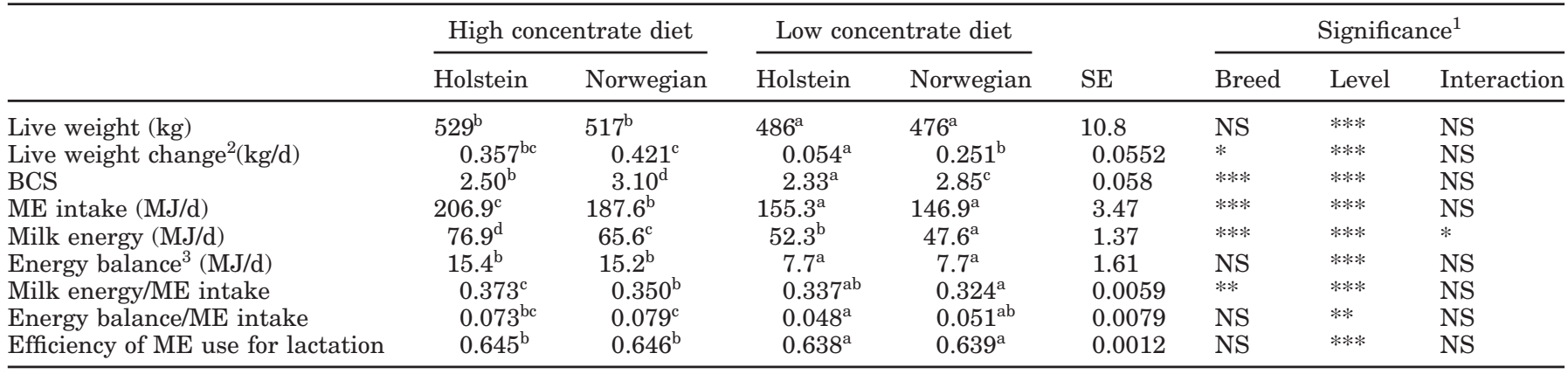

${ }^{\mathrm{a}-\mathrm{d}}$ Superscript means with the same letter in the same row are not significantly different $(P>0.05)$.

${ }^{1} \mathrm{NS}=$ Not significant $(P>0.05) ; * P<0.05 ; * * P<0.01 ; * * * P<0.001$.

${ }^{2}$ Mean difference in live weight between current and previous week and then divided by 7 .

${ }^{3}$ Energy balance was estimated from AFRC (1990).

were specially bred for high and low milk production. Dietary ME concentrations in these 3 studies were estimated from standard tabulated values for concentrates and in vitro nutrient digestibility for grass silages. However, dietary ME concentrations in the present study were measured directly for each genotype and plane of nutrition in calorimeter chambers during early, mid, and late lactation. Total ME intake (weekly mean) for cows on the production study were then calculated from dietary ME concentrations (calorimetric measurements) and DM intake (production study).

There is ample evidence to indicate that, within breed, high genetic merit cows have the ability to produce more milk energy than do low genetic merit cattle (Neilson et al., 1983; Grainger et al., 1985; Belyea and Adams, 1990; Gordon et al., 1995; Veerkamp and Emmans, 1995; Ferris et al., 1999), with similar effects being recorded between breeds (Holstein vs. Jersey cows; Tyrrell et al., 1990). In the present study, milk energy output was consistently higher with HolsteinFriesian than Norwegian cows during the whole lactation, irrespective of the plane of nutrition, although the difference was greater during early lactation and with the high concentrate diet. For example, HolsteinFriesian cows produced on average 13.3 and $5.3 \mathrm{MJ} / \mathrm{d}$ more milk energy than Norwegian cows during the whole lactation when offered the high and low concentrate diets, respectively. These differences in additional milk energy output were much higher in early lactation (21.4 and $8.3 \mathrm{MJ} / \mathrm{d}$ ) and gradually reduced for $\operatorname{mid}(11.3$ and $4.7 \mathrm{MJ} / \mathrm{d}$ ) and late (7.4 and $2.8 \mathrm{MJ} / \mathrm{d}$ ) lactation.

The higher milk energy output observed with Holstein-Friesian cows in the present study may be mainly derived from higher ME intake, when compared with Norwegian cows. The ME intake for the whole lactation with Holstein-Friesian cows was on average 18.4 and 6.7 MJ/d higher than Norwegian cows when offered the high and low concentrate diets respectively. This difference in ME intake with the high concentrate diet was consistent for early, mid, and late lactation (17.9, 19.3 , and $18.0 \mathrm{MJ} / \mathrm{d}$ respectively), although the difference with the low concentrate diet was smaller (8.9, 8.4, and 2.7 MJ/d respectively). These results are in line with findings in long-term studies with HolsteinFriesian cows (Neilson et al., 1983; Veerkamp and Emmans, 1995). Many short-term studies observed similar results using the same breed of cows (Grainger et al., 1985; Belyea and Adams, 1990; Gordon et al., 1995; Ferris et al., 1999) and different breeds (Holstein vs. Jersey cows; Tyrrell et al., 1990).

The higher milk energy output with HolsteinFriesian cows may also result from these cows partitioning more consumed energy into milk than Norwegian cows in the present study. The milk energy output as a proportion of ME intake was consistently higher with Holstein-Friesian cows than Norwegian cows during the first half of lactation (irrespective of the plane of nutrition), although the difference between 2 genotypes was reduced during the second half of lactation (Figure 3 ). The mean values for the whole lactation were significantly higher for Holstein-Friesian than Norwegian cows when offered diets containing high (0.393 vs. $0.359)$ and low (0.372 vs. 0.351$)$ levels of concentrates. However, the ability of Holstein-Friesian cows to partition more dietary ME into milk was mainly achieved during early lactation with the high concentrate diet. Milk energy as a proportion of ME intake with HolsteinFriesian cows was 18\% higher than with Norwegian cattle in early lactation with the high concentrate diet, reducing to $6 \%$ for midlactation and $2 \%$ for late lactation. The corresponding data with the low concentrate diet were 7,4 , and $6 \%$, respectively. When comparisons were made between high and low genetic merit in the same breed (Holstein-Friesian), Veerkamp et al. (1994) 

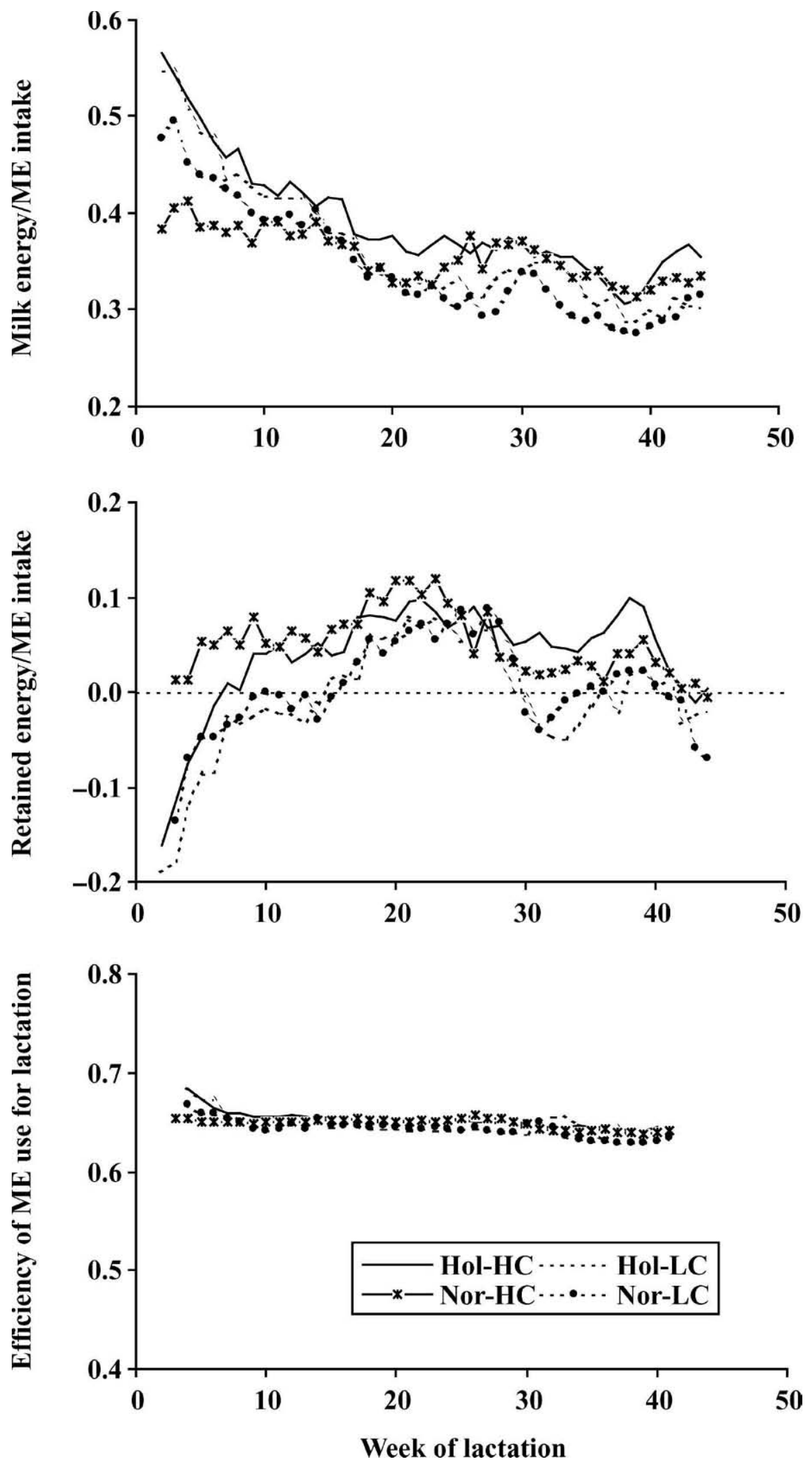

Figure 3. Effects of stage of lactation on efficiencies of ME use for milk production and body tissue balance in Holstein-Friesian (Hol) and Norwegian (Nor) cows offered high (HC) and low (LC) concentrate diets. 
Table 5. Effects of cow genotype and plane of nutrition on live weight, body condition and energy use during late lactation (wk 31 to 44 )

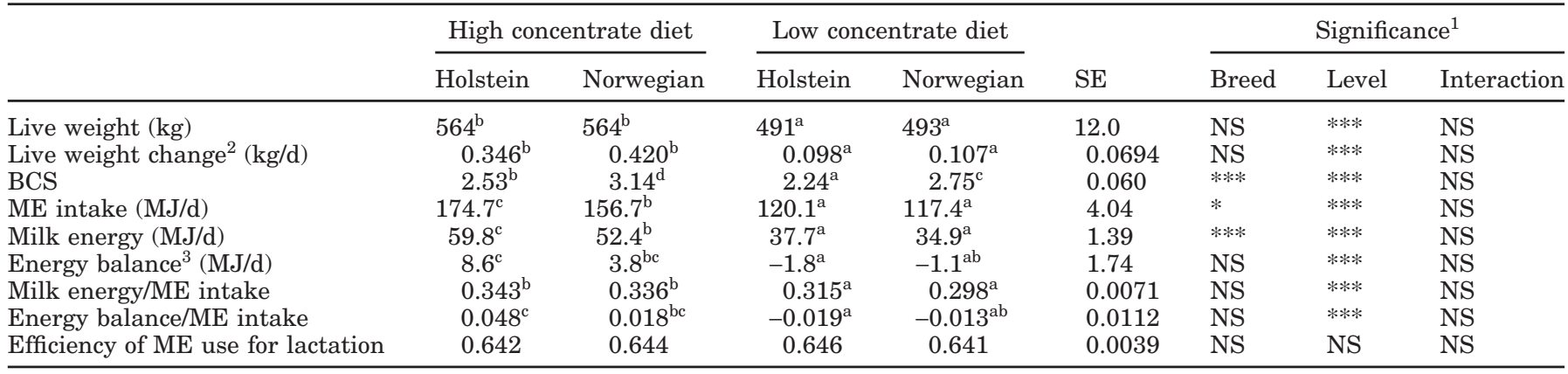

${ }^{\mathrm{a}-\mathrm{d}}$ Superscript means with the same letter in the same row are not significantly different $(P>0.05)$.

${ }^{1} \mathrm{NS}=$ Not significant $(P>0.05) ; * P<0.05 ; * * P<0.01 ; * * * P<0.001$.

${ }^{2}$ Mean difference in live weight between current and previous week and then divided by 7 .

${ }^{3}$ Energy balance was estimated from AFRC (1990).

found that milk energy output as a proportion of $\mathrm{ME}$ intake was consistently higher with high genetic merit cows during the first 26 wk of lactation. This trend was not influenced by dietary concentrate levels (high vs. low) or cow lactation number (heifer vs. multiparous). The average values over the first 26 wk of lactation were 3 to 6 percentage units higher with high than low genetic merit cows $(P<0.05$; Veerkamp et al., 1994). Similar results were also reported by Neilson et al. (1983; $P<0.001)$, Gordon et al. $(1995 ; P<0.001)$ and Ferris et al. (1999), although the difference was not significant in the latter study.

However, cows selected primarily for higher milk production also partition less energy into body tissue than do low genetic merit cows (Agnew and Yan, 2000). The findings in the present study clearly demonstrated this. Holstein-Friesian cows had a consistently lower accumulated live weight gain $(\mathrm{kg})$ and BCS than Norwegian cows during the whole lactation, irrespective of the plane of nutrition. The ratio of energy balance as a proportion of ME intake was therefore lower for Holstein-Friesian than Norwegian cows during early lactation, although the difference disappeared during late lactation. The magnitude of this difference during early lactation was greater with the high concentrate diets. There is little comparable information in the literature on the effect of cow genetic merit on the ratio of energy balance as a proportion of ME intake. Veerkamp and Emmans (1995) reported a consistently lower estimated daily energy balance with high than low-yielding Holstein-Friesian cows during the first 26 wk of lactation. Veerkamp et al. (1994) found that high-yielding Holstein-Friesian cows had a consistently lower BCS than low-yielding Holstein-Friesian cows during the first 26 wk of lactation. This difference in BCS was not influenced by plane of nutrition (high vs. low) or cow lactation number (heifer vs. multiparous).
The ability of Holstein-Friesian cows to partition more energy into milk and less into body tissue than Norwegian cows can also be demonstrated by comparing milk energy and energy balance generated from additional ME intake (Table 6). The additional ME intake, milk energy, and energy balance were calculated as the differences between data obtained from the high and low concentrate diets within each genotype, with milk energy output being adjusted to zero energy balance (AFRC, 1990) if the energy balance was negative in any of the 4 treatments. For the whole lactation, Holstein-Friesian cows had higher additional ME intake than Norwegian cows (49.7 vs. $38.0 \mathrm{MJ} / \mathrm{d}$ ), consequently produced more additional milk energy ( $23.4 \mathrm{vs.}$ $14.6 \mathrm{MJ} / \mathrm{d}$ ), but slightly less additional energy balance $(8.0$ vs. $9.0 \mathrm{MJ} / \mathrm{d})$. Therefore, Holstein-Friesian cows had a higher ratio of additional milk energy ( $0.47 \mathrm{vs.}$ 0.38 ) but a lower ratio of additional energy balance (0.16 vs. 0.24 ) as a proportion of additional $\mathrm{ME}$ intake when compared with Norwegian cows. This tendency is similar to that reported in Table 2 using daily ME intake, milk energy, and energy balance obtained for the whole lactation with either the high or low concentrate diet.

It is worth noting that the ability of Holstein-Friesian cows to partition more additional dietary ME into milk and less into body tissue is greater during early lactation (Table 6). For early lactation, Holstein-Friesian cows partitioned $66 \%$ of additional ME intake into milk with no energy partitioned to body tissue. The ratios of additional milk energy as a proportion of additional ME intake reduced to 0.48 and 0.43 for mid and late lactation, respectively, and the ratios of additional energy balance as a proportion of additional ME intake increased to 0.15 and 0.16 , respectively. However, the pattern of use of additional dietary ME with Norwegian cows is different from that observed with Holstein- 
Table 6. Efficiencies of use of additional ME intake for production at different stages of lactation ${ }^{1}$

\begin{tabular}{|c|c|c|c|c|c|c|c|c|}
\hline \multirow[b]{2}{*}{ Item $^{2}$} & \multicolumn{2}{|c|}{ Wk 2 to 44} & \multicolumn{2}{|c|}{ Wk 2 to 15} & \multicolumn{2}{|c|}{ Wk 16 to 30} & \multicolumn{2}{|c|}{ Wk 31 to 44} \\
\hline & Holstein & Norwegian & Holstein & Norwegian & Holstein & Norwegian & Holstein & Norwegian \\
\hline$\Delta \mathrm{MEI}(\mathrm{MJ} / \mathrm{d})$ & 49.7 & 38.0 & 42.9 & 33.9 & 51.6 & 40.7 & 54.6 & 39.3 \\
\hline$\Delta \mathrm{EB}_{(+)}(\mathrm{MJ} / \mathrm{d})$ & 8.0 & 9.0 & 0.0 & 9.0 & 7.7 & 7.5 & 8.6 & 3.8 \\
\hline$\Delta \mathrm{E}_{1(0)} / \Delta \mathrm{MEI}$ & 0.47 & 0.38 & 0.66 & 0.37 & 0.48 & 0.44 & 0.43 & 0.47 \\
\hline$\Delta \mathrm{EB}_{(+)} / \Delta \mathrm{MEI}$ & 0.16 & 0.24 & 0.00 & 0.27 & 0.15 & 0.18 & 0.16 & 0.10 \\
\hline$\left(\Delta \mathrm{E}_{1(0)}+\Delta \mathrm{E}_{\mathrm{g}(+)}\right) / \Delta \mathrm{MEI}$ & 0.63 & 0.62 & 0.66 & 0.64 & 0.63 & 0.62 & 0.59 & 0.56 \\
\hline
\end{tabular}

${ }^{1}$ Additional ME intake, milk energy, and energy balance are calculated as differences between data obtained from the high and low concentrate diets within each genotype.

${ }^{2} \Delta \mathrm{MEI}=$ Additional $\mathrm{ME}$ intake; $\Delta \mathrm{EB}_{(+)}=$additional positive energy balance (if $\mathrm{EB} \leq 0$, positive $\mathrm{EB}=0$; if $\mathrm{EB}>0$, positive $\mathrm{EB}=$ original value); $\Delta \mathrm{E}_{1(0)}=$ additional adjusted milk energy output (if $\mathrm{EB}<0$, adjusted $\mathrm{E}_{1}=\left(\mathrm{E}_{1}+0.84 \mathrm{~EB}\right)$; if $\mathrm{EB} \geq 0$, adjusted $\mathrm{E}_{1}=$ original value).

Friesian cattle; that is, the ratios of additional milk energy as a proportion of additional ME intake increased from 0.37 for early lactation to 0.44 and 0.47 for mid and late lactation and the ratios of additional energy balance as a proportion of additional ME intake reduced from 0.27 to 0.18 and 0.10 , respectively. The different patterns in the relative efficiencies of use of additional dietary $\mathrm{ME}$ for lactation and body gain may reflect the different approaches for a long-term genetic selection between the 2 genotypes. The primary objective of selection for Holstein-Friesian cattle was to maximize milk production, whereas selection for Norwegian cattle was in a multitrait selection procedure with disease resistance and fertility improvement being main targets along with milk production.

Lamb et al. (1977) assessed the first-lactation performance of 289 daughters of 17 Holstein sires when the animals were fed according to milk yield, and concluded that the daughters of high genetic merit bulls used less nutrients for body gain and more for milk production. The difference in partition of ME between high and low genetic merit cows is associated with insulin concentration in blood (Hart, 1983). During early lactation, insulin concentrations were significantly higher in the plasma of low genetic merit cows that were in energy surplus and gaining body weight than in high genetic merit cows that were in energy deficit and losing live weight (Hart, 1983). The difference in insulin concentration disappeared when the animals stopped lactating (Hart, 1983). This change in blood insulin concentration during lactation is clearly in line with the pattern of serum leptin concentration obtained in the present study as reported by Wylie et al. (2002). Serum leptin concentrations were much higher in Norwegian than Holstein-Friesian cattle during the first $12 \mathrm{wk}$ of lactation; thereafter, the difference gradually reduced and disappeared after $30 \mathrm{wk}$ of lactation. The change in blood hormone concentrations is also reflected in energy partitioning between milk and body tissue obtained in the present study. The energy balance as a proportion of ME intake was higher with Norwegian than Holstein-Friesian cows in early lactation $(P<$ 0.05 ), but it was similar between the 2 genotypes during mid and late lactation. In contrast, milk energy output as a proportion of ME intake was lower with Norwegian than Holstein-Friesian cows for early lactation $(P<$ 0.001). The effect carried over to midlactation with a lower significance level $(P<0.01)$, but disappeared in late lactation.

Consequently, the efficiency of ME use for lactation $\left(\mathrm{k}_{1}\right)$ appeared to be similar between the 2 genotypes in the present study when $\mathrm{ME}$ intake, $\mathrm{ME}_{\mathrm{m}}$, milk energy output, and energy balance are taken into account. There were no significant effects of cow genotype on $\mathrm{k}_{1}$ values derived from the whole lactation or mid and late lactation, although Holstein-Friesian cows had a higher $\mathrm{k}_{1}$ than Norwegian cows in early lactation when a high concentrate diet was offered. The $\mathrm{k}_{1}$ values were similar during the whole lactation irrespective of genotype or diets offered (Figure 3). This result is in accord with a number of short-term studies. Grainger et al. (1985) reported that the difference in milk energy output between high and low genetic merit cows could almost entirely be explained by differences between genotypes in energy intake and tissue energy retention. When using the equations of AFRC (1990) to estimate $\mathrm{ME}_{\mathrm{m}}$, neither Gordon et al. (1995) nor Ferris et al. (1999) detected any significant difference in $\mathrm{k}_{1}$ between high, medium, and low genetic merit cows. Tyrrell et al. (1990) used a regression technique of milk energy output and energy balance against ME intake and found no difference in energy use between Holstein and Jersey cows during early lactation. Previous studies with these 2 genotypes (Holstein and Jersey) have shown little difference in the partial efficiency with which ME is used for lactation (Veerkamp and Emmans, 1995). Agnew and Yan (2000) reviewed published calorimetric data for lactating dairy cows and concluded that $\mathrm{k}_{1}$ values were not influenced by cow genetic merit or dietary nutrient concentration (e.g., fiber content). 


\section{CONCLUSIONS}

In the present study, Holstein-Friesian cows produced more milk energy output than Norwegian cows when offered either a high or low plane of nutrition. The higher milk energy output with Holstein-Friesian cows was mainly derived from additional ME intake (12.6 MJ/d), but also the ability to partition more consumed energy into milk [milk energy/ME intake, 0.383 (Holstein-Friesian) vs. 0.355 (Norwegian)]. It is also worth noting that a higher proportion of the additional $\mathrm{ME}$ intake with the high concentrate diet when compared with the low concentrate diet was partitioned to milk energy with Holstein-Friesian cows, particularly in early lactation. This left less energy available for body tissue repletion with Holstein-Friesian cows. Although the differences in ratios of milk energy output or energy balance as a proportion of ME intake between the 2 genotypes gradually disappeared as lactation progressed, Norwegian cows had a consistently higher accumulated live weight gain and BCS than HolsteinFriesian cows during the whole lactation. In particular, Holstein-Friesian cows offered a low plane of nutrition did not fully recover their live weight or BCS (at wk 44 of lactation) relative to that recorded at wk 1 of lactation. This clearly indicates that the plane of nutrition is very important for high-yielding cows to maximize the potential of milk production and maintain body condition for the next lactation.

\section{ACKNOWLEDGMENTS}

The authors wish to thank the staff of the Dairy and Energy Metabolism Units for collection of data and care of animals. This work was funded by the Department of Agriculture and Rural Development for Northern Ireland.

\section{REFERENCES}

Agnew, R. E., and T. Yan. 2000. The impact of recent research on energy feeding systems for dairy cattle. Livest. Prod. Sci. 66:197-215.

Agricultural and Food Research Council (AFRC). 1990. Technical Committee on Responses to Nutrients, Report Number 5, Nutritive Requirements of Ruminant Animals: Energy. Nutr. Abstr. Rev. B 60:729-804.
Belyea, R. L., and M. W. Adams. 1990. Energy and nitrogen utilization of high versus low producing dairy cows. J. Dairy Sci. 73:10231030.

Ferris, C. P., F. J. Gordon, D. C. Patterson, M. G. Porter, and T. Yan. 1999. The effect of genetic merit and concentrate proportion in the diet on nutrient utilization by lactating dairy cows. J. Agric. Sci. 132:483-490.

Gordon, F. J., M. G. Porter, C. S. Mayne, E. F. Unsworth, and D. J. Kilpatrick. 1995. The effect of forage digestibility and type of concentrate on nutrient utilisation for lactating dairy cattle. J. Dairy Res. 62:15-27.

Grainger, C., C. W. Holmes, and Y. F. Moor. 1985. Performance of Friesian cows with high and low breeding indexes. 1. Energy and nitrogen balance experiments with lactating and pregnant, nonlactating cows. Anim. Prod. 40:389-400.

Hart, I. C. 1983. Endocrine control of nutrient partition in lactating ruminants. Proc. Nutr. Soc. 42:181-194.

Holstein Journal. 2000. Proof run-why has everything changed? Holstein J. 1:100-103.

Lamb, R. C., J. L. Walters, M. J. Anderson, R. D. Plowman, G. H. Mickelsen, and R. H. Miller. 1977. Effect of sire and interaction of sire with ration on efficiency of feed utilization by Holsteins. J. Dairy Sci. 60:1755-1767.

Ling, E. R. 1963. A Textbook of Dairy Chemistry. Vol. 2, 4th ed., Chapman and Hall, London, UK.

Mayne, C. S., and F. J. Gordon. 1984. The effect of type of concentrate and level of concentrate feeding on milk production. Anim. Prod. 39:65-76.

Mulvanny, P. M. 1977. Dairy cow condition scoring. Paper 4468. Natl. Inst. Res. Dairying, Reading, UK.

Neilson, D. R., C. T. Whittemore, M. Lewis, J. C. Alliston, D. J. Roberts, L. S. Hodgson-Jones, J. Mills, H. Parkinson, and J. H. D. Prescott. 1983. Production characteristics of high-yielding dairy cows. Anim. Prod. 36:321-334.

Ødegård, J., J. Jensen, G. Klemetsdal, P. Madsen, and B. Heringstad. 2003. Genetic analysis of somatic cell score in Norwegian cattle using random regression test-day models. J. Dairy Sci. 86:4103-4114.

Ranberg, I. M. A., B. Heringstad, G. Klemetsdal, M. Svendsen, and T. Steine. 2003. Heifer fertility in Norwegian dairy cattle: Variance components and genetic change. J. Dairy Sci. 86:2706-2714.

Tyrrell, H. F., and J. T. Reid. 1965. Prediction of the energy value of cow's milk. J. Dairy Sci. 48:1215-1223.

Tyrrell, H. F., C. K. Reynolds, and H. D. Baxter. 1990. Energy metabolism of Jersey and Holstein cows fed total mixed diets with or without whole cottonseed. J. Dairy Sci. 73(Suppl. 1):192. (Abstr.)

Veerkamp, R. F., and G. C. Emmans. 1995. Sources of genetic variation in energetic efficiency of dairy cows. Livest. Prod. Sci. 44:87-97.

Veerkamp, R. F., G. Simm, and J. D. Oldham. 1994. Effects of interaction between genotype and feeding system on milk production, feed intake, efficiency and body tissue mobilisation in dairy cows. Livest. Prod. Sci. 39:229-241.

Wylie, A. R. G., D. J. Devlin, T. W. J. Keady, C. S. Mayne, R. E. Agnew, and T. Yan. 2002. Post-partum blood leptin concentrations and energy balance in first calving dairy heifers. Page 91 in Proc. Br. Soc. Anim. Sci., York, UK. Br. Soc. Anim. Sci., Edinburgh, UK.

Yan, T., R. E. Agnew, F. J. Gordon, and M. G. Porter. 2000. The prediction of methane energy output in dairy and beef cattle offered grass silage-based diets. Livest. Prod. Sci. 64:253-263. 